\title{
The role of neuropeptide $Y$ and interaction with leptin in regulating feed intake and luteinizing hormone and growth hormone secretion in the pig
}

\author{
C Richard Barb ${ }^{1}$, Robert R Kraeling ${ }^{1}$, George B Rampacek ${ }^{2}$ and Gary J Hausman ${ }^{1}$ \\ ${ }^{1}$ USDA/ARS, Animal Physiology Research Unit, Russell Research Center, P O Box 5677, Athens, GA 30604-5677, \\ USA and ${ }^{2}$ Animal and Dairy Science Department, 425 River Rd., University of Georgia, Athens, GA 30602, USA \\ Correspondence should be addressed to C R Barb; Email: rbarb@saa.ars.usda.gov
}

\begin{abstract}
Two experiments (EXP) were conducted in ovariectomized prepubertal gilts to test the hypothesis that neuropeptide Y (NPY) stimulates appetite and modulates $\mathrm{LH}$ and $\mathrm{GH}$ secretion, and that leptin modifies such acute effects of NPY on feeding behavior and $L H$ and $G H$ secretion. In EXP I, gilts received intracerebroventricular (ICV) injections of $0.9 \%$ saline (saline; $n=6$ ), or $10 \mu \mathrm{g}$ $(n=7), 50 \mu \mathrm{g}(n=5)$ or $100 \mu \mathrm{g}(n=7)$ NPY in saline and blood samples were collected. In EXP II, gilts received ICV injections of S $(n=4)$, or $50 \mu \mathrm{g}$ leptin $(n=4)$, or $100 \mu \mathrm{g}$ NPY $(n=4)$ or $100 \mu \mathrm{g}$ NPY $+50 \mu \mathrm{g}$ leptin $(n=4)$ in saline, and feed intake was measured at 4, 20 and $44 \mathrm{~h}$ after feed presentation and blood samples collected. In EXP I, NPY suppressed LH secretion and the $100 \mu \mathrm{g}$ dose stimulated GH secretion. In EXP II, NPY reversed the inhibitory effect of leptin on feed intake and suppressed LH secretion, but serum GH concentrations were unaffected. These results support the hypothesis that NPY modulates feed intake, and LH and GH secretion and may serve as a neural link between metabolic state and the reproductive and growth axis in the pig.

Reproduction (2006) 131 1127-1135
\end{abstract}

\section{Introduction}

Several reports demonstrated that neuropeptide Y (NPY) is a potent regulator of feeding behavior as well as energy expenditure and fat storage (Clark et al. 1984, Billington \& Levine 1992). In addition, evidence indicates that hypothalamic NPY is responsive to changes in energy balance and blood leptin concentrations (Blum 1997). Leptin administration increased serum concentrations of luteinizing hormone ( $\mathrm{LH})$ and growth hormone $(\mathrm{GH})$ in the rodent (Carro et al. 1997, Yu et al. 1997) and in the feed-restricted ruminant (Nagatani et al. 2000, Amstalden et al. 2002). We previously reported that intracerebroventricular (ICV) administration of leptin suppressed feed intake, increased serum GH concentrations (Barb et al. 1998), and stimulated hypothalamic gonadotropinreleasing hormone $(\mathrm{GnRH})$ release in vitro (Barb et al. 2004). Central administration of NPY suppressed LH secretion in the monkey (Kaynard et al. 1990), ewe (Malven et al. 1992) and heifer (Thomas et al. 1999). In contrast, ICV infusion of NPY acutely stimulated secretion of GH in sheep (Morrison et al. 2003) and cattle (Thomas et al. 1999). Garcia et al. (2004) reported that leptin pretreatment attenuated the acute effect of
NPY on GH, but not LH secretion in the heifer. In the rat, leptin suppressed but did not block the hyperphagic response to NPY (Yokosuka et al. 1998), and NPY suppressed the leptin-induced increase in $\mathrm{GH}$ secretion in the fasted rat (Carro et al. 1998).

Neuropeptide $\mathrm{Y}$ plays a role in relaying the metabolic state of the animal to hypothalamic neurons (White 1993). The majority of NPY innervations reaching the hypothalamus arise from the arcuate nucleus (Grove \& Smith 2003) with some of these NPY neurons located outside the blood-brain barrier (Peruzzo et al. 2000). Some of the NPY fibers are adrenergic and noradrenergic nerve fibers originating in the brain stem (Fetissov et al. 2004) and the medulla oblongata (Everitt et al. 1984). The NPY receptors are distributed throughout the hypothalamus, with individual distribution patterns (Fetissov et al. 2004). Campbell et al. (2001) reported that half of $\mathrm{GnRH}$-immunopositive neurons in the medial preoptic area (MPOA) were immunoreactive for the NPY5 receptor.

Taken together the above reports support the idea that NPY could modulate hypothalamic neuronal activity and serve as a putative link between nutritional status and the growth and reproductive axis in the pig. Thus, 
changes in hypothalamic NPY concentrations as a result of feeding, fast and (or) altered metabolism may play a role in regulating appetite, $\mathrm{LH}$ and $\mathrm{GH}$ secretion.

The goal of the present study was twofold: to determine if NPY stimulates feed intake and $\mathrm{GH}$ secretion and suppresses $\mathrm{LH}$ secretion and to determine if leptin modifies such effects of NPY on feeding behavior and $\mathrm{LH}$ and $\mathrm{GH}$ secretion in the pig.

\section{Materials and Methods}

\section{Experiment (EXP) I}

Eight ovariectomized (OVX) crossbred prepubertal gilts, $90 \pm 4 \mathrm{~kg}$ body weight (BW) and 150 days of age were surgically implanted with lateral ICV cannulas using the stereotaxic procedure of Estienne et al. (1990) and Barb et al. (1993). Animals were individually penned in an environmentally controlled building at a constant temperature of $22{ }^{\circ} \mathrm{C}$ and artificial $12 \mathrm{~h}: 12 \mathrm{~h}$ light:darkness photoperiod. Pigs were fed to appetite daily, at 0800 and $1700 \mathrm{~h}$, a corn-soybean meal ration ( $14 \%$ crude protein) supplemented with vitamins and minerals, according to the National Research Council guidelines (NRC 1998). One week after the last ICV surgery, all pigs were fitted with an indwelling jugular vein cannula (Barb et al. 1982) $24 \mathrm{~h}$ before treatment. On the day of the EXP, pigs were fed at $0730 \mathrm{~h}$ and blood sampling started at $0800 \mathrm{~h}$. Blood samples were collected every $15 \mathrm{~min}$ for $3 \mathrm{~h}$ before and $4 \mathrm{~h}$ after ICV injections of $150 \mu \mathrm{l} 0.9 \%$ saline (saline, $n=2)$, or $10 \mu \mathrm{g}(n=2), 50 \mu \mathrm{g}(n=1)$ or $100 \mu \mathrm{g}(n=2)$ porcine NPY (Sigma Chemical Co., St. Louis, MO) in $150 \mu \mathrm{l}$ saline. Second and third replicates were conducted as described above with an additional 8 and 12 OVX prepubertal gilts averaging $94 \pm 6 \mathrm{~kg}$ and $68 \pm 2 \mathrm{~kg} \mathrm{BW}$ and 150 and 130 days of age respectively. One animal which received saline and two which received $50 \mu \mathrm{g}$ NPY were eliminated from the study due to loss of patency of the jugular cannula. This resulted in the following groups for the three replicates; saline $(n=6), 10 \mu \mathrm{g}(n=7), 50 \mu \mathrm{g}$ $(n=5)$ and $100 \mu \mathrm{g}(n=7)$ NPY. Serum was harvested and stored at $-20^{\circ} \mathrm{C}$ until assayed for $\mathrm{LH}$ and $\mathrm{GH}$ by radioimmunoassay (RIA). All procedures were approved by the Richard B Russell Agriculture Research Center Committee on Animal Care and Use.

\section{Experiment II}

Eight OVX crossbred prepubertal gilts, $88 \pm 5 \mathrm{~kg}$ BW and 150 days of age were surgically implanted with ICV cannulas, fitted with indwelling jugular vein cannulas and housed and fed as described above. On the day of the EXP, pigs were fed at $0730 \mathrm{~h}$ and blood sampling started at $0800 \mathrm{~h}$. Blood samples were collected every $15 \mathrm{~min}$ for $3 \mathrm{~h}$ before and $4 \mathrm{~h}$ after ICV injections of $150 \mu \mathrm{l} 0.9 \%$ saline $(n=4)$, or $50 \mu \mathrm{g}$ recombinant human leptin $(n=4$; R\&D Sytems, Minneapolis, MN, USA), or $100 \mu \mathrm{g}$ NPY $(n=4)$ or $100 \mu \mathrm{g} \mathrm{NPY}+50 \mu \mathrm{g}$ leptin $(n=4)$ in $150 \mu \mathrm{l}$ of saline. Four days later, the EXP was replicated with pigs reassigned to treatment such that no pig received the same treatment a second time, resulting in 4 pigs/treatment. After the last sample was collected, feeders were placed in all pens and feed intake monitored at 4, 20 and $44 \mathrm{~h}$ after feed presentation. Serum was harvested and stored at $-20^{\circ} \mathrm{C}$ until assayed for $\mathrm{LH}$ and $\mathrm{GH}$ by RIA.

\section{Radioimmunoassays}

Serum samples were assayed for GH (Barb et al. 1991) and LH (Kesner et al. 1987) as previously described. Sensitivity of the assays was $0.4 \mathrm{ng} / \mathrm{ml}$ and $0.15 \mathrm{ng} / \mathrm{ml}$ for $\mathrm{GH}$ and $\mathrm{LH}$ respectively. Intra- and interassay coefficients of variation were 4.5 and $10.2 \%$ for $\mathrm{LH}$ and 3.5 and $13 \%$ for $\mathrm{GH}$ respectively.

\section{Statistical analysis}

To determine the effect of NPY on feed intake and LH and $\mathrm{GH}$ secretion, data were subjected to the general linear model split plot-in-time ANOVA procedure of the Statistical Analysis System (SAS 1999). The statistical model included dose, pig, time and replicate. Effects of treatment and replicate were tested using replicate $\times$ treatment as the error term. Replicate $\times$ treatment was tested using pig within treatment $\times$ replicate as the error term. Time and time $\times$ treatment were tested using treatment $\times$ time $\times$ replicate as the error term. Differences between treatment means within a time were determined by least-squares contrasts (SAS 1999). For each gilt in EXP I and II, mean serum hormone concentrations, basal hormone concentrations, the number of hormone pulses and hormone pulse amplitude were determined for $\mathrm{LH}$ and $\mathrm{GH}$ by Pulsar analysis, using a $1 \%$ criterion of variation (Merriam \& Wachter 1982) during the post-treatment period. Data were then subjected to one-way ANOVA.

\section{Results \\ Experiment I}

A treatment $\times$ time interaction was detected for serum LH $(P<0.0005)$ and $\mathrm{GH}(P<0.06)$ concentrations. Serum LH levels decreased $(P<0.05)$ by $45 \mathrm{~min}$ after injection of $10 \mu \mathrm{g}(0.9 \pm 0.2 \mathrm{ng} / \mathrm{ml}), 50 \mu \mathrm{g}(0.8 \pm$ $0.2 \mathrm{ng} / \mathrm{ml})$ and $100 \mu \mathrm{g}(0.9 \pm 0.2 \mathrm{ng} / \mathrm{ml})$ NPY compared with saline $(1.4 \pm 0.2 \mathrm{ng} / \mathrm{ml})$ treatment (Fig. 1). Injection of $100 \mu \mathrm{g}$ NPY suppressed mean $(P<0.04)$ and basal serum LH $(P<0.02)$ concentrations and $\mathrm{LH}$ pulse frequency $(P<0.04$; Table 1$)$. Only the $100 \mu \mathrm{g}$ dose of NPY increased $(P<0.05) \mathrm{GH}$ secretion by $15 \mathrm{~min}(4.6 \pm$ $0.5 \mathrm{ng} / \mathrm{ml})$ after treatment compared to saline $(2.2 \pm$ $0.5 \mathrm{ng} / \mathrm{ml}$; Fig. 2), while the indices of $\mathrm{GH}$ secretion were unaffected by NPY treatment (Table 2). 


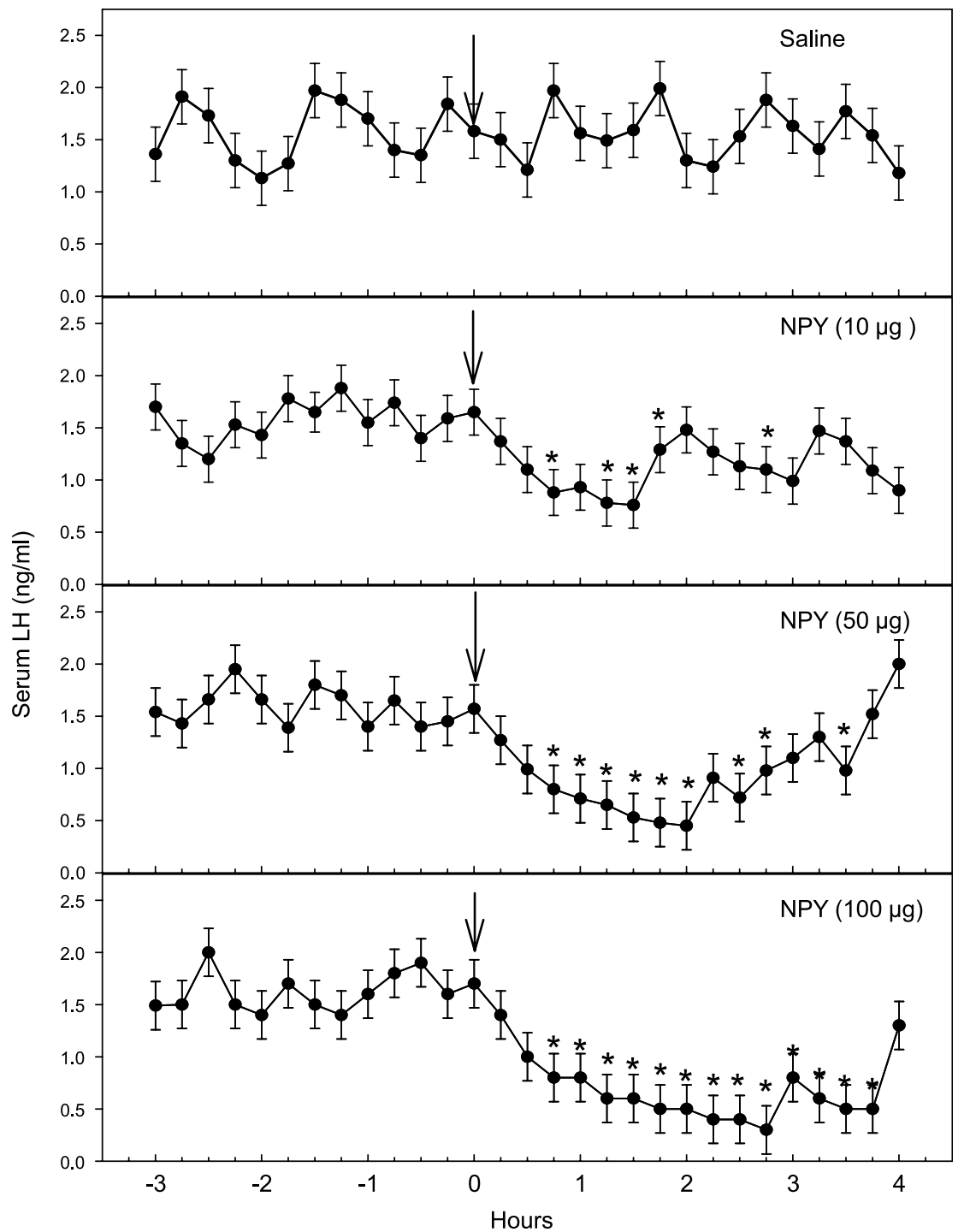

Figure 1 Serum LH concentrations (means \pm S.E.M.) for OVX prepubertal gilts receiving ICV injections of saline (saline; $n=6$ ), or $10 \mu \mathrm{g}$ NPY $(n=7), 50 \mu \mathrm{g}$ NPY $(n=5)$, or $100 \mu \mathrm{g}$ NPY $(n=7)$ at time $0 \mathrm{~h}$ (arrow). A treatment $\times$ time interaction was detected $(P<0.0005)$. *Times at which effects of treatment were different from saline-treated animals $(P<0.05)$.

\section{Experiment II}

A treatment $\times$ time interaction was detected for feed intake $(P<0.001)$. At $4 \mathrm{~h}$, feed intake was lower $(P<$ 0.04) in NPY- and NPY + leptin-treated animals compared with saline-treated pigs (Fig. 3). By $20 \mathrm{~h}$, feed intake was lower $(P<0.04)$ in leptin-treated pigs, but higher $(P<0.04)$ in NPY- and NPY + leptin- treated pigs $(P<0.04)$. A treatment $\times$ time interaction was detected for $\mathrm{LH}(P<0.004)$. Serum $\mathrm{LH}$ concentrations decreased $(P<0.01)$ by hour 2 after NPY and NPY + leptin (Fig. 4). Administration of NPY and NPY + leptin suppressed LH pulse frequency $(P<0.02$; Table 3$)$. Serum GH concentrations (Fig. 5) and indices of $\mathrm{GH}$ secretion (Table 4) were unaffected by treatment.

Table 1 Mean and basal serum LH concentrations, LH pulse frequency and LH pulse amplitude after intraventricular injection of saline $(n=6)$, or 10 $(n=7), 50(n=5)$ or $100 \mu$ g neuropeptide Y (NPY; $n=7)$. Values expressed as mean \pm s.E.M.

\begin{tabular}{lcccc}
\hline & \multicolumn{3}{c}{ Treatment } \\
\cline { 2 - 4 } Parameter & Saline & $10 \mu \mathrm{g}$ NPY & $50 \mu \mathrm{g}$ NPY & $100 \mu \mathrm{g}$ NPY \\
\hline Mean LH $(\mathrm{ng} / \mathrm{ml})$ & $1.5 \pm 0.2^{\mathrm{b}}$ & $1.1 \pm 0.2^{\mathrm{b}}$ & $0.9 \pm 0.2^{\mathrm{b}}$ & $0.6 \pm 0.2^{\mathrm{c}}$ \\
Basal LH $(\mathrm{ng} / \mathrm{ml})$ & $1.2 \pm 0.1^{\mathrm{b}}$ & $0.9 \pm 0.1^{\mathrm{b}}$ & $0.6 \pm 0.1^{\mathrm{c}}$ & 0.04 \\
LH pulse/4 h & $3.9 \pm 0.6^{\mathrm{b}}$ & $2.7 \pm 0.6^{\mathrm{b}}$ & $2.4 \pm 0.6^{\mathrm{b}}$ & $0.1^{\mathrm{c}}$ \\
LH pulse amplitude $(\mathrm{ng} / \mathrm{ml})^{\mathrm{a}}$ & $1.0 \pm 0.5$ & $1.1 \pm 0.5$ & $1.2 \pm 0.5$ & 0.02 \\
\hline
\end{tabular}

${ }^{\mathrm{a} A m p l i t u d e}=$ pulse height - basal concentration. ${ }^{\mathrm{b}, \mathrm{c}}$ Means in a row differ $P$-values present in table. 


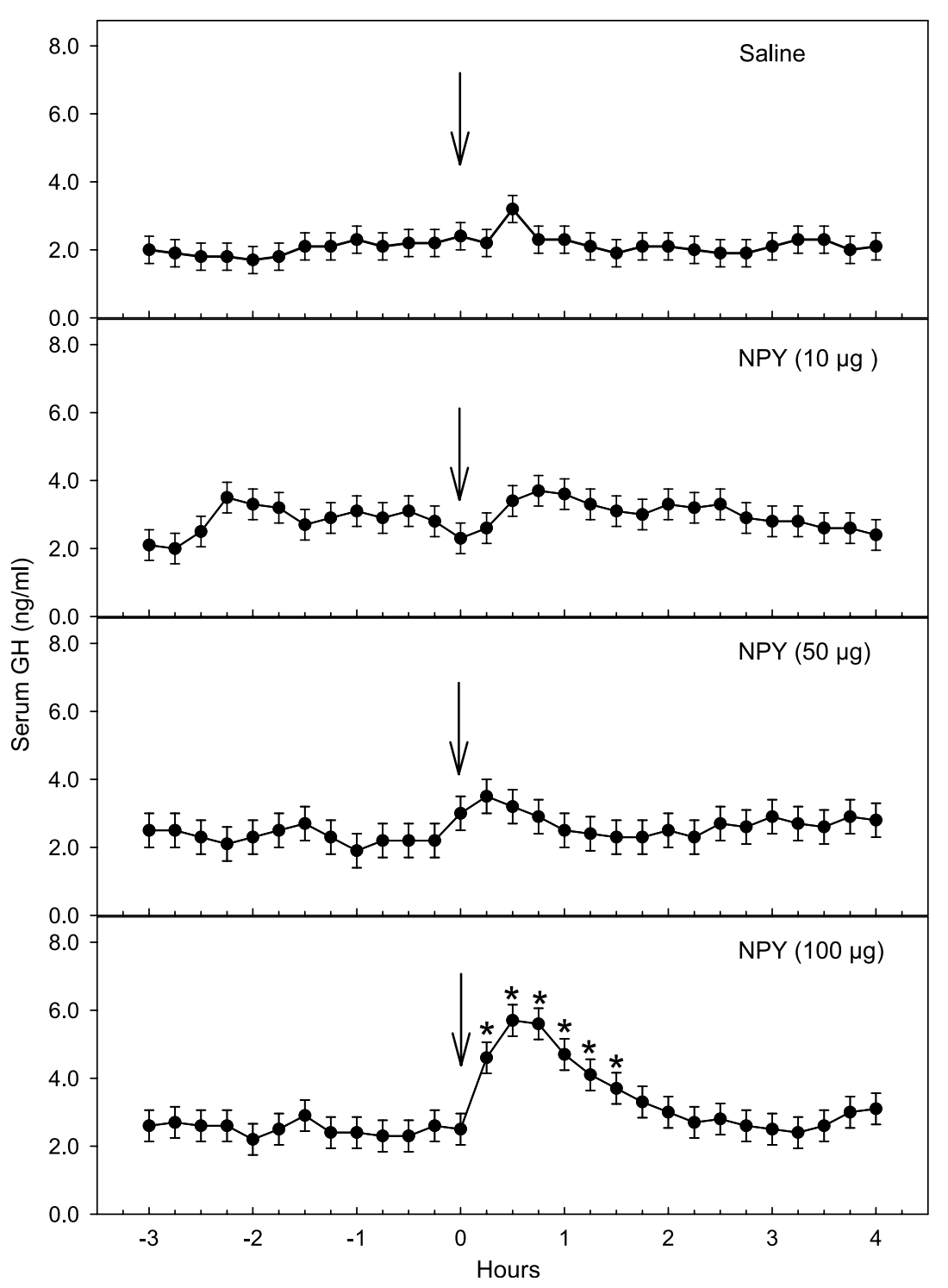

Figure 2 Serum $\mathrm{GH}$ concentrations (means \pm s.E.M.) for OVX prepubertal gilts receiving ICV injections of saline (saline; $n=6)$, or $10 \mu \mathrm{g}$ NPY $(n=7), 50 \mu \mathrm{g} \mathrm{NPY}$ $(n=5)$, or $100 \mu \mathrm{g} \mathrm{NPY}(n=7)$ at time $0 \mathrm{~h}$ (arrow). A treatment $X$ time interaction was detected $(P<0.06)$. *Times at which effects of treatment were different from saline-treated animals $(P<0.05)$.

\section{Discussion}

In the present study, central administration of NPY reduced serum $\mathrm{LH}$ concentrations and $\mathrm{LH}$ pulse frequency in EXP I and II. This is in agreement with previous reports in the OVX cow (Thomas et al. 1999) and the OVX oestradiol-implanted ewe (Morrison et al. 2003).
Furthermore, central administration of NPY in the OVX and OVX oestradiol-implanted cow resulted in a marked reduction in GnRH and LH secretion (Gazal et al. 1998) suggesting a hypothalamic site of action. However, a pituitary site of action of NPY on LH secretion has been reported for cattle (Denniston et al. 2003). Thus, at least in

Table 2 Mean and basal serum GH concentrations, GH pulse frequency and GH pulse amplitude after intraventricular injection of saline $(n=6)$, or $10(n=7), 50(n=5)$ or $100 \mu \mathrm{g}$ neuropeptide Y (NPY; $n=7)$. Values expressed as mean \pm s.E.M.

\begin{tabular}{lcccc}
\hline & \multicolumn{3}{c}{ Treatment } \\
\cline { 2 - 4 } Parameter & Saline & $10 \mu \mathrm{g}$ NPY & $50 \mu \mathrm{g}$ NPY & $100 \mu \mathrm{g}$ NPY \\
\hline Mean GH $(\mathrm{ng} / \mathrm{ml})$ & $2.4 \pm 0.8$ & $3.2 \pm 0.8$ & $3.4 \pm 0.9$ & $3.7 \pm 0.8$ \\
Basal GH $(\mathrm{ng} / \mathrm{ml})$ & $2.3 \pm 0.7$ & $3.2 \pm 0.8$ & $3.2 \pm 0.8$ & $3.7 \pm 0.8$ \\
$\mathrm{GH}$ pulse/4 & $0.7 \pm 0.3$ & $0.6 \pm 0.3$ & $1.2 \pm 0.4$ & $0.4 \pm 0.3$ \\
GH pulse amplitude $(\mathrm{ng} / \mathrm{ml})^{\mathrm{a}}$ & $0.6 \pm 0.4$ & $0.4 \pm 0.4$ & $0.9 \pm 0.4$ & 0.5 \\
\hline
\end{tabular}

${ }^{\mathrm{a} A m p l i t u d e}=$ pulse height - basal concentration. 


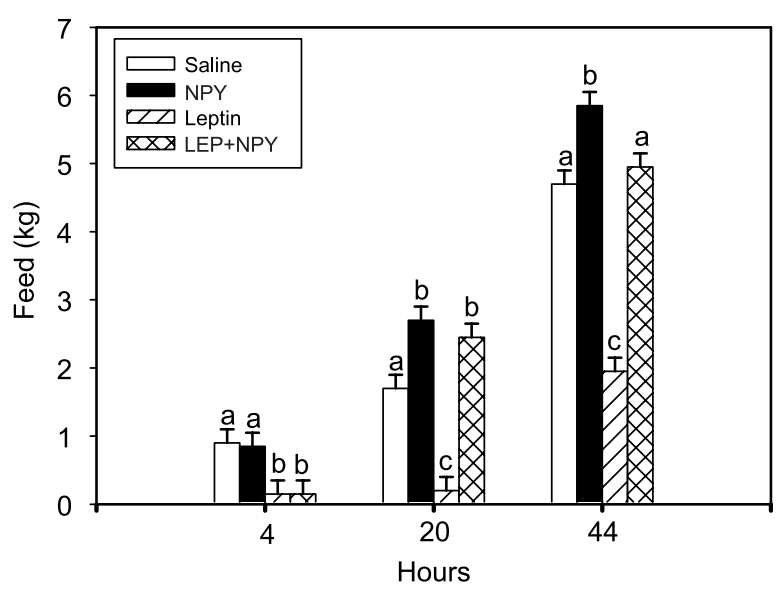

Figure 3 Cumulative feed intake (mean \pm S.E.M) for OVX prepubertal gilts receiving ICV injections of saline (saline; $n=4)$, or $100 \mu \mathrm{g}$ NPY $(n=4)$, or $50 \mu \mathrm{g}$ leptin $(n=4)$, or NPY $(100 \mu \mathrm{g})+$ leptin $(50 \mu \mathrm{g}$; LEP + NPY; $n=4)$. Feed intake was monitored at 4,24 and $44 \mathrm{~h}$ after feed presentation. ${ }^{\mathrm{a}, \mathrm{b}, \mathrm{c}}$ Times at which effects of treatment differ $(P<0.04)$.

part, the action of NPY on LH secretion may occur at the anterior pituitary in cattle. In contrast to the bovine, we reported that NPY failed to affect $\mathrm{LH}$ secretion in porcine anterior pituitary cells in culture (Barb \& Barrett 2005), supporting the idea of a hypothalamic site of action in the pig. The observed action of NPY on LH secretion and feed intake in the present study along with reports that nutritional status modulated hypothalamic NPY expression (Brady et al. 1990, Adam et al. 1997) supports the notion that NPY serves as a link between metabolic state and the reproductive axis in the pig.

The presence of biologically active leptin receptors (Lin et al. 2001), NPY and its receptor (Busch-Sorensen et al. 1989) and GnRH (Kineman et al. 1988, Lin et al. 2001) in the porcine hypothalamus suggest that NPY and leptin could interact to modulate $\mathrm{GnRH} / \mathrm{LH}$ pulse generation. The failure of leptin to block the NPYinduced decrease in $\mathrm{LH}$ secretion is similar to that reported for the OVX cow in which leptin pretreatment failed to prevent the NPY-induced inhibition of LH secretion (Garcia et al. 2004). These observations suggest that NPY is acting post-synaptically to overcome the leptin-induced reduction in NPY and other leptinsensitive pathways that influence $\mathrm{GnRH}$ neuronal activity. This would suggest that NPY plays a primary role in the leptinergic pathways modulating $\mathrm{LH}$ secretion. Furthermore, administration of NPY counteracted the inhibitory action of leptin on feed intake by $20 \mathrm{~h}$ post-treatment in the present study. It is possible that NPY could be acting through parallel pathways to alter

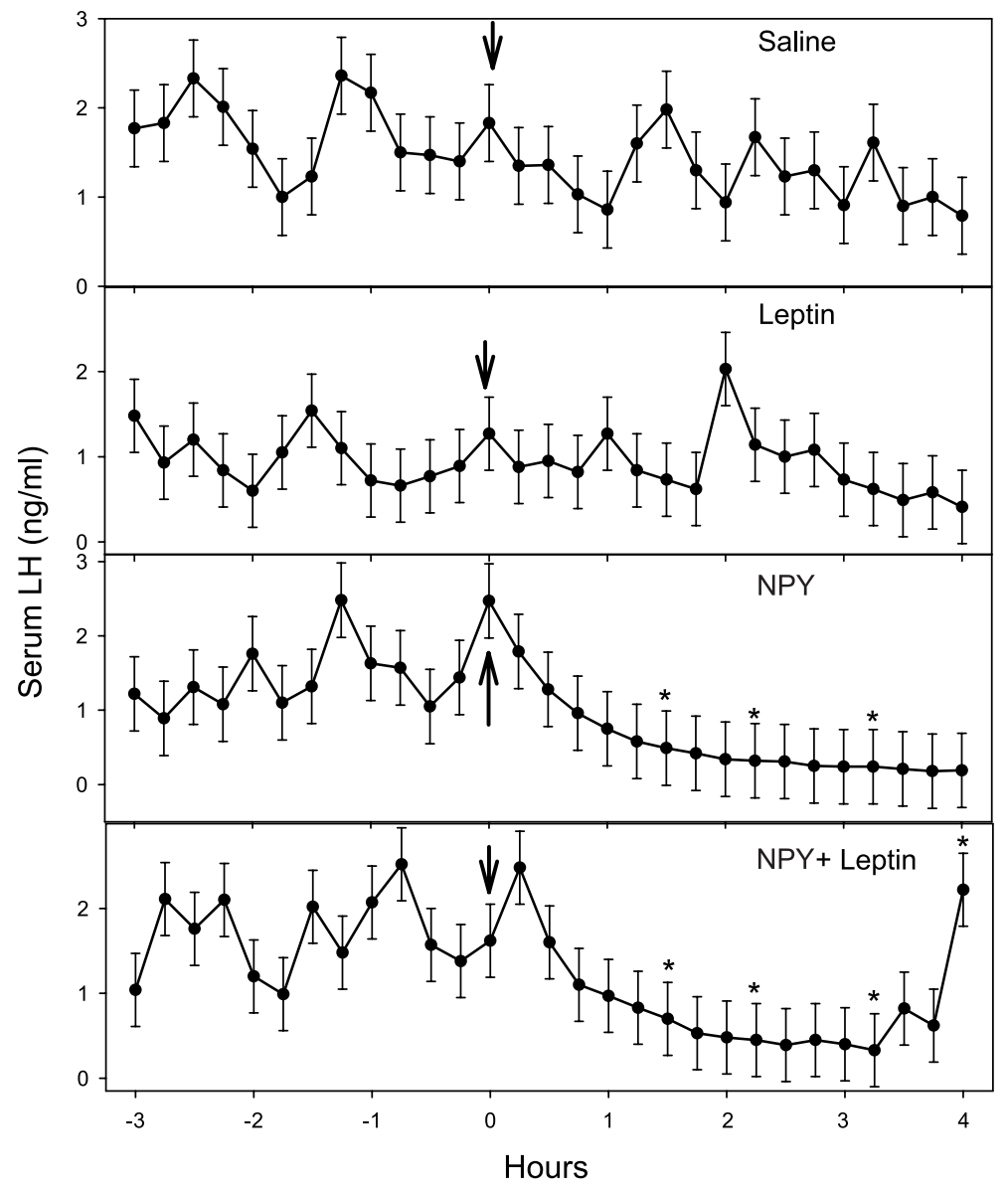

Figure 4 Serum LH concentrations (means \pm s.E.M.) for OVX prepubertal gilts receiving ICV injections of saline (saline; $n=4)$, or $100 \mu \mathrm{g} \mathrm{NPY}(n=4)$, or $50 \mu \mathrm{g}$ leptin $(n=4)$, or NPY $(100 \mu \mathrm{g})+$ leptin $(50 \mu \mathrm{g} ; n=4)$ at time $0 \mathrm{~h}$ (arrow). A treatment $\times$ time interaction was detected $(P<0.004)$. ${ }^{*}$ Times at which effects of treatment were different from saline-treated animals $(P<0.05)$. 
Table 3 Mean and basal serum LH concentrations, LH pulse frequency and LH pulse amplitude after intraventricular injection of saline $(n=4)$, or leptin $(50 \mu \mathrm{g} ; n=4)$, neuropeptide Y $(100 \mu \mathrm{g} \mathrm{NPY;} n=4)$ or NPY + leptin $(n=4)$. Values expressed as mean \pm s.E.M.

\begin{tabular}{|c|c|c|c|c|c|}
\hline \multirow[b]{2}{*}{ Parameter } & \multicolumn{4}{|c|}{ Treatment } & \multirow[b]{2}{*}{$P$ value } \\
\hline & Saline & Leptin & NPY & NPY + Leptin & \\
\hline Mean LH (ng/ml) & $1.3 \pm 0.3$ & $0.9 \pm 0.3$ & $0.6 \pm 0.3$ & $1.3 \pm 0.3$ & 0.5 \\
\hline Basal LH (ng/ml) & $1.0 \pm 0.2$ & $0.6 \pm 0.2$ & $0.6 \pm 0.2$ & $0.7 \pm 0.2$ & 0.3 \\
\hline LH pulse $/ 4 \mathrm{~h}$ & $2.8 \pm 0.4^{b}$ & $2.3 \pm 0.4^{b}$ & $0^{\mathrm{c}}$ & $1.3 \pm 0.4^{\mathrm{c}}$ & 0.02 \\
\hline LH pulse amplitude $(\mathrm{ng} / \mathrm{ml})^{\mathrm{a}}$ & $1.3 \pm 1.0$ & $1.7 \pm 1.0$ & 0 & $3.9 \pm 1.0$ & 0.2 \\
\hline
\end{tabular}

${ }^{\mathrm{a}}$ Amplitude $=$ pulse height - basal concentration. ${ }^{\mathrm{b}, \mathrm{c}}$ Means in a row differ $P$-values present in table.

feeding behavior and LH secretion. Thus, NPY could act directly or indirectly to inhibit $\mathrm{GnRH} / \mathrm{LH}$ release and stimulate feeding behavior. A similar hypothesis has been proposed for the interaction of leptin and NPY in the regulation of $\mathrm{GH}$ secretion in the rat (Carro et al. 1998). In support of this hypothesis, co-localization of leptin receptor mRNA with NPY gene expression was found in the arcuate nuclei (ARC; Cunningham et al. 1999). In addition, the paraventricular nucleus (PVN), the feeding center, receives neural projections from the arcuate nuclei (Kalra et al. 1999). This is an area rich in NPY-containing pre-synaptic nerve terminals and post-synaptic NPY receptors (Bai et al. 1985, Chronwall et al. 1985). NPY could act post-synaptically to suppress ARC GnRH neuronal activity and stimulate NPY sensitive neurons in the PVN, thereby counteracting the leptin-induced reduction in NPY within the PVN. This may also account for the delayed hyperphagic response to NPY observed in the NPY + leptin-treated animals.

Several reports demonstrated that central administration of NPY stimulates feeding behavior in the rodent (Clark et al. 1984, McDonald et al. 1989), monkey (Kaynard et al. 1990) and human (Kaye et al. 1990). This

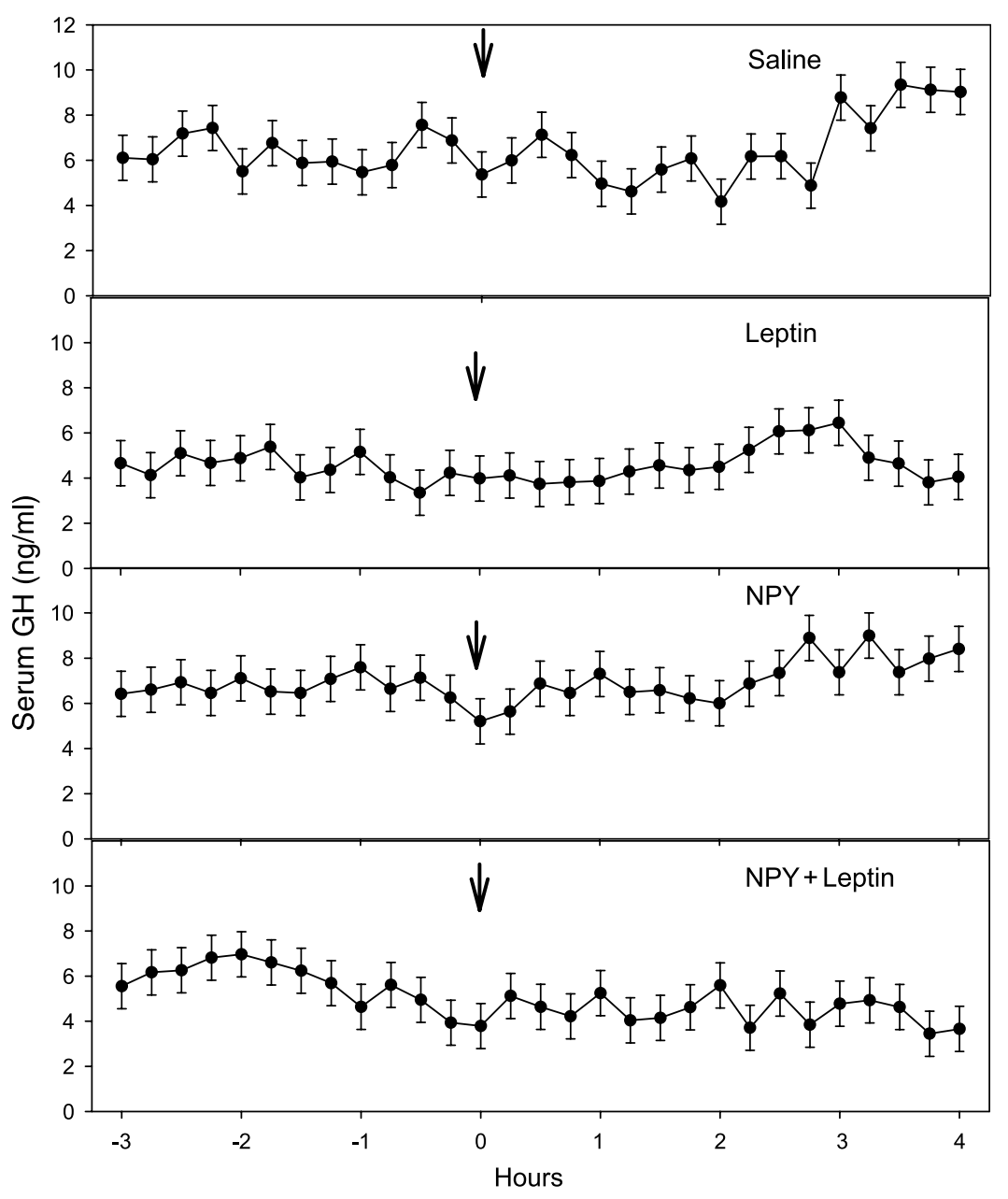

Figure 5 Serum $\mathrm{GH}$ concentrations (means \pm S.E.M.) for OVX prepubertal gilts receiving ICV injections of saline (saline; $n=4)$, or $100 \mu \mathrm{g}$ NPY $(n=4)$, or $50 \mu \mathrm{g}$ leptin $(n=4)$, or NPY $(100 \mu \mathrm{g})+$ leptin $(50 \mu \mathrm{g} ; n=4)$ at time $0 \mathrm{~h}$ (arrow). 
Table 4 Mean and basal serum GH concentrations, GH pulse frequency and $\mathrm{GH}$ pulse amplitude after intraventricular injection of saline $(n=4)$, or leptin (50 $\mu \mathrm{g} ; n=4)$, neuropeptide Y $(100 \mu \mathrm{g}$ NPY; $n=4)$ or NPY + leptin $(n=4)$. Values expressed as mean \pm S.E.M.

\begin{tabular}{lcccc}
\hline & \multicolumn{3}{c}{ Treatment } \\
\cline { 2 - 4 } Parameter & Saline & Leptin & NPY & NPY + Leptin \\
\hline Mean GH $(\mathrm{ng} / \mathrm{ml})$ & $6.7 \pm 1.2$ & $4.9 \pm 1.2$ & $6.9 \pm 1.2$ & $4.7 \pm 1.2$ \\
Basal GH $(\mathrm{ng} / \mathrm{ml})$ & $6.3 \pm 1.1$ & $4.5 \pm 1.1$ & $6.9 \pm 1.1$ & 0.1 \\
$\mathrm{GH}$ pulse/4 $\mathrm{h}$ & $2.0 \pm 0.5$ & $1.0 \pm 0.5$ & $0.6 \pm 0.5$ & $1.3 \pm 1.1$ \\
$\mathrm{GH}$ pulse amplitude $(\mathrm{ng} / \mathrm{ml})^{\mathrm{a}}$ & $3.8 \pm 2.0$ & $1.0 \pm 2.0$ & $0.5 \pm 2.0$ & 0.3 \\
\hline
\end{tabular}

${ }^{\mathrm{a}}$ Amplitude $=$ pulse height - basal concentration.

is the first report in the pig to demonstrate that acute ICV administration of NPY increased cumulative feed intake. In satiated operant trained pigs, central injection of NPY increased the total number of operant feeding responses during the $30 \mathrm{~min}$ post-treatment period (Parrott et al. 1986). However, the temporal pattern of feeding responses measured at $5 \mathrm{~min}$ intervals revealed an apparent reduction in feeding responses by $20 \mathrm{~min}$ after treatment. In the present study the stimulatory effect of NPY on feeding behavior was not observed until $20 \mathrm{~h}$ after treatment. The apparent dichotomy between the studies may be accounted for, at least in part, by the methods used to measure feed intake and duration of the measurement period. Work in the rodent demonstrated different hypothalamic sites of action for NPY and leptin (Kalra et al. 1999). The leptin-induced suppression of NPYstimulated feeding observed in the rodent was associated with attenuation of a subset of magnocellular PVN neurons and activation of dorsomedial neurons (DMN; Yokosuka et al. 1998) and a reduction in the availability of NPY at the nerve terminal in the PVN (Schwartz et al. 1996). Since the orexigenic and anorexigenic signal pathways are apparently linked, this may account for the delay in the ability of NPY to reactivate the appetite-stimulating signal.

The inability of leptin to increase LH secretion in the present study was not unexpected and may be attributed to nutritional status. Similar reports demonstrated that chronic ICV administration of leptin failed to stimulate $\mathrm{LH}$ secretion in well-nourished OVX ewes with no steroid replacement (Henry et al. 1999), and in intact ewe lambs (Morrison et al. 2001), whereas, in the feedrestricted OVX cow (Amstalden et al. 2002) and ewe (Henry et al. 2001), central administration of leptin stimulated LH secretion. It is possible that the dose of leptin was inadequate to elicit a response, but this is unlikely since the same dose of leptin suppressed feed intake in the present study. A more plausible explanation for the failure of leptin to increase LH secretion may be attributable to the use of satiated animals.

Stimulation of GH secretion by NPY in EXP I is similar to that reported in the OVX ewe (Morrison et al. 2003) and cow (Thomas et al. 1999, Garcia et al. 2004). Thomas et al. (1999) reported that NPY stimulated GH secretion in OVX cows but did not affect tonic secretion patterns of $\mathrm{GH}$, which is similar to results reported in the present study. These reports differ from rats, in which NPY inhibited the secretion of $\mathrm{GH}$ via stimulation of somatostatin secretion (Quintela et al. 1997). In contrast, NPY appears to stimulate growth hormonereleasing hormone $(\mathrm{GHRH})$ and somatostatin release in ruminants (McMahon et al. 2001). McMahon et al. (2001) proposed that different subpopulations of NPY neurons may mediate secretion of GHRH and somatostatin independently, either via the same or different receptor subtypes. This may account for the diverse effects of NPY on GH secretion between species and physiological states. Alternatively, a pituitary site of action cannot be discounted, since NPY stimulated GH secretion from porcine pituitary cells in culture (Barb \& Barrett 2005).

The almost total lack of GH response to NPY observed in EXP II may, in part, be due to the inability of NPY to exceed a putative stimulatory threshold of hypothalamic $\mathrm{GHRH}$ and somatostatin neurons to effect a release of $\mathrm{GH}$. This is consistent with the observation that pretreatment serum $\mathrm{GH}$ concentrations were approximately threefold greater in EXP II pigs compared with serum GH levels in EXP I animals. Moreover, pretreatment serum GH concentrations in EXP II were similar to the maximal $\mathrm{GH}$ concentration in response to $100 \mu \mathrm{g}$ NPY in EXP I, suggesting a possible change in the activity and (or) sensitivity of GHRH and somatostatin neurons. McMahon et al. (2000) observed a reduction of somatostatin and GHRH neuronal activity associated with decreasing $\mathrm{GH}$ concentrations during feeding. Thus, serum GH concentrations may reflect changes in the activity and (or) sensitivity of GHRH and somatostatin neurons. Furthermore, the effects of NPY on LH secretion lasted longer than those for $\mathrm{GH}$ secretion in EXP I, indicating a difference in the sensitivity of the LH and GH secretory axes to NPY.

In conclusion, the presence of NPY and its receptor (Busch-Sorensen et al. 1989), GnRH (Kineman et al. 1988, Lin et al. 2001) and GHRH (Leshin et al. 1994) in the porcine hypothalamus coupled with current results support the hypothesis that NPY may serve as a neural link between metabolic state and the reproductive and growth axis in the pig. 


\section{Acknowledgements}

The authors wish to thank B Barrett, E A Taras, R Utley and B Johnson for their technical assistance. The authors wish to thank Dr A F Parlow, Harbor-UCLA Medical Center, Torrance, CA for providing the porcine GH antiserum AFP-1021854. This research was supported by USDA funds and State and Hatch funds allocated to the Georgia Agricultural Experiment Station. Mention of a trade name, proprietary product, or specific equipment does not constitute a guarantee or warranty by the US Department of Agriculture or the University of Georgia and does not imply its approval to the exclusion of other products which may be suitable. The authors declare that there is no conflict of interest that would prejudice the impartiality of this scientific work.

\section{References}

Adam CL, Findlay PA, Kyle CE, Young P \& Mercer JG 1997 Effect of chronic food restriction on pulsatile luteinizing hormone secretion and hypothalamic neuropeptide $\mathrm{Y}$ gene expression in castrate male sheep. Journal of Endocrinology 152 329-337.

Amstalden M, Garcia MR, Stanko RL, Nizielski SE, Morrison CD, Keisler DH \& Williams GL 2002 Central infusion of recombinant ovine leptin normalizes plasma insulin and stimulates a novel hypersecretion of luteinizing hormone after short-term fasting in mature beef cows. Biology of Reproduction 66 1555-1561.

Bai FL, Yamano M, Shiotani Y, Emson PC, Smith AD, Powell JF \& Tohyama M 1985 An aruato-paraventricular and -dorsomedial hypothalamic neuropeptide Y-containing system that lacks noradrenalin in the rat. Brain Research 331 172-175.

Barb CR \& Barrett JB 2005 Neuropeptide Y modulates growth hormone secretion but not luteinizing hormone secretion from prepubertal gilt anterior pituitary cells in culture. Domestic Animal Endocrinology 29 548-555.

Barb CR, Barrett JB \& Kraeling RR 2004 Role of leptin in modulating the hypothalamic-pituitary axis in the pig. Domestic Animal Endocrinology 26 201-214.

Barb CR, Estienne MJ, Kraeling RR, Marple DN, Rampacek GB, Rahe CH \& Sartin JL 1991 Endocrine changes in sows exposed to elevated ambient temperature during lactation. Domestic Animal Endocrinology 8 117-127.

Barb CR, Kraeling RR, Estienne MJ \& Rampacek GB 1993 Technique for cannulation of the lateral ventricle of the brain in swine. Kopf Carrier 35 1-5.

Barb CR, Kraeling RR, Rampacek GB, Fonda ES \& Kiser TE 1982 Inhibition of ovulation and $\mathrm{LH}$ secretion in the gilt after treatment with ACTH or hydrocortisone. Journal of Reproduction and Fertility 64 85-92.

Barb CR, Yan X, Azain MJ, Kraeling RR, Rampacek GB \& Ramsay TG 1998 Recombinant porcine leptin reduces feed intake and stimulates growth hormone secretion in swine. Domestic Animal Endocrinology 15 77-86.

Billington CJ \& Levine AS 1992 Hypothalamic neuropeptide $Y$ regulation of feeding and energy metabolism. Current Opinions Neurobiology 2 847-851.

Blum WF 1997 Leptin: The voice of the adipose tissue. Hormone Research 48 2-8.

Brady LS, Smith MA, Gold PW \& Herkenham M 1990 Altered expression of hypothalamic neuropeptide mRNAs in food-restricted and food-deprived rats. Neuroendocrinology 52 441-447.

Busch-Sorensen M, Shiekh SP, Tortora O, Schwartz TW \& Gammeltoft S 1989 Regional distribution of neuropeptide $Y$ and its receptor in the porcine central nervous system. Journal of Neurochemistry $\mathbf{5 2}$ 1545-1552.
Campbell RE, French-Mullen JM, Cowley MA, Smith MS \& Grove KL 2001 Hypothalamic circuitry of neuropeptide $Y$ regulation of neuroendocrine function and food intake via the Y5 receptor subtype. Neuroendocrinology 74 106-119.

Carro E, Senaris R, Considine RV, Casanueva FF \& Dieguez C 1997 Regulation of in vivo growth hormone secretion by leptin. Endocrinology 138 2203-2206.

Carro E, Seoane LM, Senaris R, Considine RV, Casanueva FF \& Dieguez C 1998 Interaction between leptin and neuropeptide $Y$ on in vivo growth hormone secretion. Neuroendocrinology 68 187-191.

Chronwall BM, DiMaggio DA, Massari VJ, Pickel VM, Ruggiero DA \& O'Donohue TL 1985 The anatomy of neuropeptide Y containing neurons in the rat brain. Neuroscience 15 159-181.

Clark JT, Kalra PS, Crowley WR \& Kalra SP 1984 Neuropeptide Y and human pancreatic polypeptide stimulated feeding behavior in rats. Endocrinology 115 427-429.

Cunningham MJ, Clifton DK \& Steiner RA 1999 Leptin's action on the reproductive axis: perspectives and mechanisms. Biology of Reproduction $60216-222$.

Denniston DJ, Thomas MG, Kane KK, Roybal CN, Canales L, Hallford DM, Remmenga MD \& Hawkins DE 2003 Effect of neuropeptide $Y$ on $\mathrm{GnRH}$-induced $\mathrm{LH}$ release from bovine anterior pituitary cell cultures derived from heifers in a follicular, luteal or ovariectomized state. Animal Reproduction Science 78 25-31.

Estienne MJ, Kesner JS, Barb CR, Kraeling RR, Rampacek GB \& Estienne CE 1990 Gonadotropin and prolactin secretion following intraventricular administration of morphine in gilts. Proceedings of the Society for Experimental Biology and Medicine 193 92-97.

Everitt BJ, Hokfelt T, Terenius L, Tatemoto K, Mutt V \& Goldstein M 1984 Differential co-existence of neuropeptide Y (NPY)-like immunoreactivity with catecholamines in the central nervous system of the rat. Neuroscience 11 443-462.

Fetissov SO, Kopp J \& Hokfelt T 2004 Distribution of NPY receptors in the hypothalamus. Neuropeptides 38 175-188.

Garcia MR, Amstalden M, Keisler DH, Raver N, Gertler A \& Williams GL 2004 Leptin attenuates the acute effects of centrally administered neuropeptide $\mathrm{Y}$ on somatotropin but not gonadotropin secretion in ovariectomized cows. Domestic Animal Endocrinology 26 189-200.

Gazal OS, Leshin LS, Stanko RL, Thomas MG, Keisler DH, Anderson LL \& Williams GL 1998 Gonadotropin-releasing hormone secretion into third-ventricle cerebrospinal fluid of cattle: correspondence with the tonic and surge release of luteinizing hormone and its tonic inhibition by suckling and neuropeptide Y. Biology of Reproduction 59 676-683.

Grove KL \& Smith MS 2003 Ontogeny of the hypothalamic neuropeptide Y system. Physiology and Behavior 79 47-63.

Henry BA, Goding JW, Alexander WS, Tilbrook AJ, Canny BJ, Dunshea F, Rao A, Mansell A \& Clarke IJ 1999 Central administration of leptin to ovariectomized ewes inhibits food intake without affecting the secretion of hormones from the pituitary gland: evidence for a dissociation of effects on appetite and neuroendocrine function. Endocrinology 140 1175-1182.

Henry BA, Goding JW, Tilbrook AJ, Dunshea FR \& Clarke IJ 2001 Intracerebroventricular infusion of leptin elevates the secretion of luteinizing hormone without affecting food intake in long-term foodrestricted sheep, but increases growth hormone irrespective of bodyweight. Journal of Endocrinology 168 67-77.

Kalra SP, Dube MG, Pu S, Xu B, Horvath TL \& Kalra PS 1999 Interacting appetite-regulating pathways in the hypothalamic regulation of body weight. Endocrine Reviews 20 68-100.

Kaye WH, Berrettini W, Gwirtsman H \& George DT 1990 Altered cerebrospinal fluid neuropeptide $\mathrm{Y}$ and peptide $\mathrm{YY}$ immunoreactivity in anorexia and bulimia nervosa. Archives of General Psychology 47 548-556.

Kaynard AH, Pau K-YF, Hess DL \& Spies HG 1990 Third-ventricular infusion of neuropeptide $Y$ suppresses luteinizing hormone secretion in ovariectomized rhesus macaques. Endocrinology 127 24372444. 
Kesner JS, Kraeling RR, Rampacek GB \& Johnson B 1987 Absence of an estradiol-induced surge of luteinizing hormone in pigs receiving unvarying pulsatile gonadotropin-releasing hormone stimulation. Endocrinology 121 1862-1869.

Kineman RD, Leshin LS, Crim JW, Rampacek GB \& Kraeling RR 1988 Localization of luteinizing hormone-releasing hormone in the forebrain of the pig. Biology of Reproduction 39 665-672.

Leshin LS, Barb CR, Kiser TE, Rampacek GB \& Kraeling RR 1994 Growth hormone-releasing hormone and somatostatin neurons within the porcine and bovine hypothalamus. Neuroendocrinology 59 251-264.

Lin J, Barb CR, Kraeling RR \& Rampacek GB 2001 Developmental changes in the long form leptin receptor and related neuropeptide gene expression in the pig brain. Biology of Reproduction 641614 1618.

Malven PV, Haglof SA \& Degroot H 1992 Effects of intracerebral administration of neuropeptide- $Y$ on secretion of luteinizing hormone in ovariectomized sheep. Brain Research Bulletin 28 871-875

McDonald JK, Lumpkin MD \& Depaolo LV 1989 Neuropeptide-Y suppresses pulsatile secretion of luteinizing hormone in ovariectomized rats: possible site of action. Endocrinology 125 186-191.

McMahon CD, Chapin LT, Lookingland KJ, Radcliff RP \& Tucker HA 2000 Feeding reduces activity of growth hormone-releasing hormone and somatostatin neurons. Experimental Biology Medicine (Maywood.) 223 210-217.

McMahon CD, Radcliff RP, Lookingland KJ \& Tucker HA 2001 Neuroregulation of growth hormone secretion in domestic animals. Domestic Animal Endocrinology 20 65-87.

Merriam GR \& Wachter KW 1982 Algorithms for the study of episodic hormone secretion. American Journal of Physiology 243 E310-E318.

Morrison CD, Daniel JA, Hampton JH, Buff PR, McShane TM, Thomas MG \& Keisler DH 2003 Luteinizing hormone and growth hormone secretion in ewes infused intracerebroventricularly with neuropeptide Y. Domestic Animal Endocrinology $\mathbf{2 4}$ 69-80.

Morrison CD, Daniel JA, Holmberg BJ, Djiane J, Raver N, Gertler A \& Keisler DH 2001 Central infusion of leptin into well-fed and undernourished ewe lambs: effects on feed intake and serum concentrations of growth hormone and luteinizing hormone. Journal of Endocrinology 168 317-324.
Nagatani S, Zeng Y, Keisler DH, Foster DL \& Jaffe CA 2000 Leptin regulates pulsatile luteinizing hormone and growth hormone secretion in the sheep. Endocrinology 141 3965-3975.

NRC 1998 Nutrient Requirements of Swine, Washington, DC: National Academy Press.

Parrott RF, Heavens RP \& Baldwin BA 1986 Stimulation of feeding in the satiated pig by intracerebroventricular injection of neuropeptide Y. Physiology and Behavior 36 523-525.

Peruzzo B, Pastor FE, Blazquez JL, Schobitz K, Pelaez B, Amat P \& Rodriguez EM 2000 A second look at the barriers of the medial basal hypothalamus. Experimental Brain Research 132 10-26.

Quintela M, Señaris R, Heiman ML, Casanueva FF \& Dieguez C 1997 Leptin inhibits in vitro hypothalamic somatostatin secretion and somatostatin mRNA levels. Endocrinology 138 5641-5644.

SAS 1999 SAS User's Guide (Release 8.0), Cary, NC: Statistical Analysis Systems Institute, Inc.

Schwartz MW, Baskin DG, Bukowski TR, Kuijper JL, Foster D, Lasser G, Prunkard DE, Porte D Jr, Woods SC, Seeley RJ \& Weigle DS 1996 Specificity of leptin action on elevated blood glucose levels and hypothalamic neuropeptide $\mathrm{Y}$ gene expression in ob/ob mice. Diabetes 45 531-535.

Thomas MG, Gazal OS, Williams GL, Stanko RL \& Keisler DH 1999 Injection of neuropeptide $\mathrm{Y}$ into the third cerebroventricle differentially influences pituitary secretion of luteinizing hormone and growth hormone in ovariectomized cows. Domestic Animal Endocrinology 16 159-169.

White JD 1993 Neuropeptide Y: a central regulator of energy homeostasis. Regulatory Peptides 49 93-107.

Yokosuka M, Xu B, Pu S, Kalra PS \& Kalra SP 1998 Neural substrates for leptin and neuropeptide $Y$ (NPY) interaction: hypothalamic sites associated with inhibition of NPY-induced food intake. Physiology and Behavior 64 331-338.

Yu WH, Kimura M, Walczewska A, Karanth S \& McCann SM 1997 Role of leptin in hypothalamic-pituitary function. PNAS 94 1023-1028.

Received 12 January 2006

First decision 9 February 2006

Revised manuscript received 22 February 2006

Accepted 7 March 2006 